\title{
Perbedaan Effektifitas Pemberian Jus Jambu Biji Merah dan Konsumsi Sereal terhadap Perubahan Kadar Hemoglobin pada Ibu hamil di Pustu Pojok Wilayah Kerja Puskesmas Sukorame Kota Kediri
}

\author{
Galuh Pradian Yanuaringsih $^{1}$, Anis Nikmatul Nikmah ${ }^{1}$ \\ ${ }^{1}$ Fakultas Ilmu Kesehatan Universitas Kadiri \\ Corresponding author: Galuh Pradian (galuhpradian@unik-kadiri.ac.id) \\ Received 1 September 2018; Accepted 6 September 2018; Published 24 September 2018
}

\begin{abstract}
One ways to increase hemoglobin degree of pregnant woman is by consuming guava juice and cereal. Tomato and cereal contains vitamin $\mathrm{C}$ which faster the iron absorption, while cereal contains high iron and vitamin $\mathrm{C}$ which can fulfill the pregnant mothers need. The purpose of this research is to know the differentiate of effectiveness guava juice and cereal giving toward the degree of hemoglobin of pregnant woman. The sample is 26 which divide into 13 for guava juice and 13 for cereal consumption. The design research is used Quasy Experiment with Two group pretest posttest design approach by using t test. The result shows that guava juice is more effective to increase hemoglobin degree for pregnant woman in Puskesmas Sukorame, Kediri. It is hoped, this research will give benefit for pregnant woman as alternative to increase hemoglobin degree.
\end{abstract}

Keywords: Pregnancy, guava juice, sereal, hemoglobin

Copyright @ 2018 STIKes Surya Mitra Husada

All rights reserved.

This is an open-acces article distributed under the terms of the Creative Commons Attribution-ShareAlike 4.0 International License.

\section{PENDAHULUAN}

Kehamilan adalah suatu karunia yang begitu di dambakan bagi seorang wanita. Selama masa kehamilan biasanya seorang wanita mengalami banyak perubahan dan berbagai macam keluhan, oleh karena itu ibu harus selalu memperhatikan dan menjaga buah kehamilanya dengan baik. Proses kehamilan diawali bersatunya sel telur dan sperma, kemudian dilanjutkan dengan pembelahan pembelahan dan implantasi dalam Rahim ( Baety,2011).

Status gizi pada waktu pembuahan dan selama hamil dapat mempengaruhi pertumbuhan janin yang sedang di kandung. Status gizi pada trimester pertama akan sangat berpengaruh terhadap pertumbuhan embrio pada masa perkembangan dan pembentukan organ-organ tubuh (organogenesis). Adapun kelainan atau gangguan kehamilan yang sering terjadi mual muntah,rasa lelah yang berat,hipertensi,anemia dan lain - lain. Untuk mengurangi resiko atau mengatasi gangguan 
tersebut,sangat dianjurkan bagi ibu hamil mengkonsumsi makanan makanan bernutrisi tinggi. Hal ini bertujuan untuk memenuhi asupan gizi selama hamil (Aizid,2010).

Berdasarkan survey yang dilakukan di Puskesman Sukorame pada buda September didapatkan dari 13 ibu hamil yang menderita anemia sebanyak 7 (56,6\%) orang. Hal ini menunjukkan tingginya kejadian anemia di Puskemas Sukorame.

Anemia adalah suatu keadaan di mana kadar hemoglobin dalam darah di bawah normal. Hal ini bisa disebabkan oleh kurangnya zat gizi untuk pembentukan darah, seperti kekurangan zat besi, asam folat ataupun vitamin B12. Anemia yang paling sering terjadi terutama pada ibu hamil adalah anemia karena kekurangan zat besi $(\mathrm{Fe})$, sehingga lebih dikenal dengan istilah Anemia Gizi Besi (AGB). Anemia defisiensi besi merupakan salah satu gangguan yang paling sering terjadi selama kehamilan (Sulistyoningsih, 2011).

Upaya pencegahan dan penanggulangan anemia gizi besi dilaksanakan melalui pemberian Tablet Tambah Darah (TTD) yang diprioritaskan pada ibu hamil, karena prevalensi anemia pada kelompok ini cukup tinggi. Selain suplementasi Tablet Tambah Darah harus diimbangi dengan konsumsi makanan yang mengandung zat besi.Berdasarkan data yang dikutip dari (Nutrient data for this listing was provided by USDA, 2009) menyatakan bahwa dalam seratus gram sereal mengandung $31,8 \mathrm{mg}$ Fe dan 24,4 mg vitamin $\mathrm{C}$ berdasarkan kandungan tersebut menunjukkan sereal merupakan makanan selain dari hewani yang memiliki kadar Fe dan vitamin $\mathrm{C}$ tinggi yang dapat mencukupi kebutuhan ibu hamil anemia defisiensi besi, selain mengandung Fe tinggi sereal juga murah dan mudah untuk dikonsumsi apabila dibandingkan dengan sumber hewani yang mahal dan memerlukan proses pengolahan.

Salah satu buah yang sangat kaya vitamin C adalah Jambu biji. Kandungan Vitamin C pada jambu biji setara dengan 6 kali kandungan vitamin $C$ pada jeruk, 10 kali kandungan vitamin $C$ pada pepaya, 17 kali kandungan vitamin $\mathrm{C}$ pada jambu air, dan 30 kali kandungan Vitamin $\mathrm{C}$ pada pisang. (Hadieti dan Apriyanti, 2015).

Tujuan penelitian Untuk Mengetahui Perbedaan Effektifitas Pemberian Jus Jambu Biji Merah dan Konsumsi Sereal terhadap perubahan Kadar Hemoglobin pada Ibu hamil di Pustu Pojok Wilayah Kerja Puskesmas Sukorame Kota Kediri.

\section{BAHAN DAN METODE}

Rancangan penelitian ini menggunakan Design Quasy Eksperiment dengan menggunakan pendekatan Two Group Pre Test Post Test Design kemudian berdasarkan tujuan penelitian termasuk jenis penelitian perlakuan, dan menggunakan data primer.

Sampel penelitian ini adalah semua ibu hamil di Pustu Pojok Wilayah Kerja Puskesmas Sukorame kota Kediri yang berjumlah 26 responden yang dibagi 13 untuk Kelompok jus Jambu Biji Merah dan 13 untuk konsumsi sereal.

Teknik pengambilan sample menggunakan teknik total populasi. Selanjutnya untuk menganalisis perbedaan effektifitas pemberian Jus Jambu Biji Merah dan Konsumsi Sereal pada ibu hamil di Pustu Pojok Wilayah Kerja Puskesmas Sukorame Kota Kediri menggunakan Uji Beda TTest dengan taraf kesalahan $5 \%$ atau dianggap bermakna jika $\rho<0,05$.

\section{HASIL DAN PEMBAHASAN}

Kadar Hemoglobin pada ibu hamil sebelum diberikan Jus jambu Biji Merah dan Konsumsi Seral di Pustu Pojok Wilayah Kerja Puskesmas Sukorame Kota Kediri.

Tabel 1 Distribusi Frekuensi Kadar Hemoglobin Sebelum diberikan Jus Jambu Biji Merah dan Konsumsi Seral di Pustu Pojok Wilayah Kerja Puskesmas Sukorame kota Kediri

\begin{tabular}{lccccc}
\hline Variabel & $\mathrm{N}$ & Min & Max & Mean & SD \\
\hline Sebelum jambu & 13 & 10.2 & 12.5 & 11.462 & .7687 \\
\hline Sebelum sereal & 13 & 9.4 & 12.3 & 10.531 & .8321 \\
\hline
\end{tabular}


Berdasarkan Tabel 1 dapat diintrepertasikan bahwa rata - rata Kadar Hemoglobin pada Ibu hamil sebelum diberikan Jus Jambu Biji Merah dan Konsumsi Sereal adalah 11,4 untuk Jus Jambu Biji Meraj dan 10, 53 untuk Konsumsi Sereal.

Tabel 2 Distribusi Frekuensi Kadar Hemoglobin Sebelum diberikan Jus Jambu Biji Merah dan Konsumsi Seral di Pustu Pojok Wilayah Kerja Puskesmas Sukorame kota Kediri

\begin{tabular}{llllll}
\hline Variabel & $\mathrm{N}$ & Min & Max & Mean & SD \\
\hline Setelah jambu & 13 & 11.1 & 13.7 & 12.531 & .6701 \\
\hline Setelah sereal & 13 & 11.0 & 12.9 & 11.869 & .6102 \\
\hline
\end{tabular}

Berdasarkan Tabel 2 dapat diintrepertasikan bahwa rata - rata Kadar Hemoglobin pada Ibu hamil setelah diberikan Jus Jambu Biji Merah dan Konsumsi Sereal adalah 12,5 untuk Jus Jambu Biji Merah dan 11, 86 untuk Konsumsi Sereal.

Tabel 3 Perbedaan Effektifitas Pemberian Jus Jambu Biji Merah dan Konsumsi Sereal terhadap perubahan Kadar Hemoglobin pada Ibu hamil di Pustu Pojok Wilayah Kerja Puskesmas Sukorame kota Kediri

\begin{tabular}{llll}
\hline Kadar HB & Mean & SD & SE \\
\hline setelah jambu & 12.531 & .6701 & .1858 \\
\hline setelah sereal & 11.869 & .6102 & .1692 \\
\hline \multicolumn{5}{c}{$\rho$ value $=0.01$} & $\alpha=0,05$ \\
\hline
\end{tabular}

Berdasarkan tabel 3 dengan uji T- test didapatkan $\rho$ value $=0.01(\rho$ value $<\alpha)$ Sehingga dapat disimpulkan bahwa $\mathrm{H}_{0}$ ditolak dan $\mathrm{H}_{1}$ diterima berarti ada Perbedaan effektifitas Pemberian Jus Jambu Biji Merah dan Konsumsi Sereal terhadap Kadar Hemoglobin pada ibu Hamil, berdasarkan tabel diatas didapatkan Jus Jambu Biji merah lebih effektif dalam perbahan kadar Hemoglobin pada ibu hamil.

\section{PEMBAHASAN}

Berdasarkan uji statistic dapat diintrepretasikan bahwa kadar hemoblobin pada ibu hamil sebelum dan sesudah diberikan jus jambu biji merah dan konsumsi sereal didapatkan $\rho$ value $=0.01$ ( $\rho$ value $<\alpha$ ). Sehingga berarti ada Perbedaan effektifitas Pemberian Jus Jambu Biji Merah dan Konsumsi Sereal terhadap Kadar Hemoglobin pada ibu Hamil. Dengan rata kadar $\mathrm{Hb}$ sesudah diberikan Jus Jambu Biji Merah 12,5 dan konsumsi Seral 11,8 sehingga dapat disimpulkan bahwa jus Jambu Biji Merah Lebih Efektif terhadap perubahan kadar Hb pada ibu hamil.

Pada hasil penelitian didapatkan hasil kadar $\mathrm{Hb}$ pada kelomok jus jambu biji merah masih tergolong normal dan pada konsumsi sereal tergolong anemia ringan. Setelah diberikan jus jambu biji merah dan konsumsi sereal tergolong anemia sendang. Setelah diberikan jus jambu biji merah dan konsumsi sereal mengalami peningkatan kadar Hemoglobin.

Menurut Sianturi (2012) Buah jambu biji merah mengandung senyawa yang dapat meningkatkan kadar hemoglobin dalam darah, antara lain: zat besi, vitamin C, vitamin A, tembaga dan fosfor. Zat besi merupakan mineral yang diperlukan untuk mengangkut oksigen ke seluruh tubuh. Kekurangan zat besi dalam tubuh bisa membuat seseorang mengalami penurunan system kekebalan tubuh dan sering merasa lesu. Hal ini sejalan dengan penelitian yang dilakukan oleh (Andiyani, 2017) yang mengatakan bahwa ada pengaruh jus jambu biji merah terhadap kadar HB ibu hamil.

Menurut penelitian yang dilakukan oleh (Galuh, 2016) konsumsi sereal mampu meningkatkan kadar HB pada ibu hamil. Sereal mengadung Vitamin C yang juga menghambat pembentukan hemosiderin yang sulit dimobilisasi untuk membebaskan zat besi bila diperlukan oleh tubuh. Absorpsi 
zat besi dalam bentuk non heme meningkat empat kali lipat bila ada vitamin C.Vitamin $\mathrm{C}$ berperan dalam memindahkan zat besi dari transferin di dalam plasma ke ferritin hati.

Jambu Biji merah lebih effektif meningkatkan kadar $\mathrm{Hb}$ pada ibu hamil karena mengandung Vit C 6 kali lipat lebih banyak dari pada kadungan Vit Pada Jeruk. (Hadieti dan Apriyanti, 2015).

Berdasarkan hasil penelitian dapat disimpulkan bahwa jus jambu biji merah lebih effektif meningkatkan kadar $\mathrm{Hb}$ pada ibu Hamil.

\section{SIMPULAN DAN SARAN}

Ada Perbedaan Effektifitas Pemberian Jus Jambu Biji Merah dan Konsumsi Sereal terhadap perubahan Kadar Hemoglobin pada Ibu hamil di Pustu Pojok Wilayah Kerja Puskesmas Sukorame Kota Kediri 2018.

\section{DAFTAR PUSTAKA}

Adiyani, Nurul. (2017). Pengaruh Jus Jambu Biji Terhadap Perubahan Kadar Hemoglobin Ibu Hamil Trimester III Yang Mengkonsumsi Tablet Fe Di Puskesmas Pakualaman Yogyakarta, Universitas Aisyiah Jogjakarta.

Baety. (2011). Biology Reproduks Kehamilan dan persalinan. Jogjakarta: Graha Ilmu.

Galuh, Pradian. (2016). Pengaruh Konsumsi Sereal Terhadap Perubahan Kadar Hemoglobin Pada Ibu Hamil Anemia Di Wilayah Kerja Puskesmas Sukorame Kota Kediri Tahun 2016, Jurnal Keperawatan Stikes Hang Tuah Surabaya, Vol 12 no 1.

Hadiati., \& Apriyanti. (2015). Bertanam Jambu Biji di Pekarangan. Jakarta: Agriflo.

Sianturi, C. (2012). Pengaruh Vitamin C pada Penyerapan Zat Besi Non Heme. Medan: FMIPA UNM.

Sulistyoningsih, Hariyani. (2011). Gizi Untuk Kesehatan Ibu dan Anak. Yogyakarta: Graha Ilmu. 